\title{
HOLISM IN HEALTH CARE IN UNCONSCIOUS PATIENTS
}

\author{
Ĺudmila Miženková, Beáta Kollárová, Danka Boguská
}

\author{
University of Presov
}

Miženková L., Kollárová B., Boguská D. (2014), Holism in health care in unconscious patients. Health Problem of Civilization, 4 (8), p. 61-64

\begin{abstract}
Summary: Nowadays nursing focuses the care on the whole person with his instantaneous and potential health problems. The main role in the care of patients has a nurse, who perceives a patient as a unique, holistic being and not only merely his parts. She is increasingly interested in the link of physical, mental, social and spiritual needs. It is in the most important for the patient's health, well- being and his survival to apply the new dimension of a holistic approach in nursing, which means the quality of patient's life. One of the groups of patients hospitalized in intensive care units creates the patients who are unconscious, they have various injuries of many vital body systems and some of them can have irreversible damages as well. The aim of their treatment is the minimum of harm to the body and then, if possible, patient return to optimal functioning in the society. The right choice of methods for systematic and comprehensive approach is essential to provide holistic nursing care.
\end{abstract}

Keywords: holism, patient needs, unconsciousness, nurse, holistic nursing care

\section{Introduction}

Efforts to maintain a balance between technology and the needs of individuals in nursing should lead to the application of a holistic approach to people. "A holistic approach requires a focus on biological, psychological, social and spiritual aspects of health and disease. Application of a holistic philosophy cares for the health of people and stresses that the nurse has to take into account the person as a whole and must simultaneously try to understand the relationship of the parts in relation to the whole interaction and relationship to the whole of his body parts "(Pavlíková, 2006).

Holistic nursing as well as holistic medicine treats the whole person - body and psyche, as opposed to methods which focus on body parts, symptoms or diseases. It requires a new approach to the patients, but to their own health and diseases (Morton, Fontaine, Gallo, 2005). "Holistic nursing care accepts the rights of patients that are an integral part of treatment and healing process. An integral part of holistic nursing is the nursing process, which is a systematic approach and comprehensive solution to the patient problems. The main objective is to improve the quality of nursing care to the extent that it respects the individual needs of patients and increases their satisfaction. The result of this treatment is that one of their needs can meet all aspects. Each person is unique, has his typical characteristics, attitudes, beliefs and needs that affect his behaviour, expressions and reactions. In an unconscious patient following characteristics, attitudes, views and needs are influenced by the disease and the changed environment. Therefore the needs and requirements are appeared in patient which are not showed in the state of health.

Development of intensive care and emergency resuscitation can bring dramatic, sophisticated, positive diagnostic and treatment options, ambivalence, ethical - philosophical questions and problems associated with caring for critically ill patients (Rybarova, Argayova, 2011). Intensive care of patients always provides a comprehensive and individual care which is provided because of helping the patient at the moment as much as possible. The anaesthetic - resuscitation department is receiving patients who have imminent failure of basic life functions, or those who have been in this failure. Such as the patient resuscitation care is provided, the extent of nursing care is dependent on the diagnosis and medical condition of the patient. As the patient health is constantly evolving and the needs and demands for nursing care are evolving as well. An unconscious patient deprives his mobility, self-sufficiency, and decision bedridden him. He is completely dependent on others, is located in a subdivision. Activity of others (family, relatives and friends) can help him. Rhythm of life is determined by interventions from the patient's surroundings and not himself, e.g. doctors, nurses, physiotherapists, and etc. It is

Address for correspondence: L'udmila Miženková, Faculty of Health Care, University of Presov, Partizánska 1, 080 01 Prešov, Slovakia, e-mail: ludmila.mizenko@gmail.com, phone: 051/75 62447

Tables: 0 Figures: 3 References: 8, Full-text PDF www.hpc.edu.pl Copyright (C) Pope John Paul II State School of Higher Education in Biała Podlaska Sidorska 95/97, 21-500 Biała Podlaska Indexation: Index Copernicus, Database AGRO, ProQuest, Polish Ministry of Science and Higher Education. This is an open-access article distributed under the terms of the Creative Common Attribution Non-commercial license (http://creativecommons. org/licenses/by-nc/3.0), which permits use, distribution and reproduction in any medium, provided the original works is properly cited, the use is non-commercial and is otherwise in compliance with the license. 
important that the nurse is perfectly aware of all his needs, and they are fully satisfied. The rate of knowledge and needs of the patient depend on what a nurse needs to know how and is able to apply this knowledge into practice. Assess the unconscious person condition is one of the most important role of a nurse work (Horńáková, 2008). "From a nursing perspective, a nurse should know about the needs of the patients enough to recognize their rights to know and understand them in her professional nursing knowledge and skills to ensure patient satisfaction, affect and coordination.

The nurse should realize: what is activated the patient, as diseases are modifying current method and limiting to addressing the basic biological needs of life and disease-emerged, so far unknown needs, how it affects the patient's illness and social conditions as they are reflected back to the patient, to initiate the creation of new needs, how known needs of patients will influence to prevent any frustration of developing a complication and the resulting new needs (Kapounová, 2007). "The unconscious patient needs can be met by healthy or even harmful way. The question is whether to meet the physiological and psychological needs of the unconscious patients by largely objective judgments of nurses, but can also by subjective to the patient who is conscious. Among the factors that impede meeting the needs of the patient is disease, human individuality (personality), interpersonal relationships, human development stage, the circumstances in which the disease arises“ (Trachtová et al., 2001). A need for breathing, nutrition, emptying, self-sufficiency and psychological balance are the most common needs of patients in intensive care. Kapounová (Kapounová, 2007) points out that to prevent the patient psychological well- being may contribute to the following factors to the maximum extent possible with regard to their diagnosis and health as: maintain or improve patient self-sufficiency, eliminate or minimize pain, communicate, to ensure sufficient rest and sleep, create a feeling of security and safety.

\section{The aim of work}

We try to check differentiations in knowledge and practical implementation of a holistic approach to an unconscious patient in the context of professional development of nurses and the places of occupation in the Anaesthetic-Intensive Care methodology (AIM) workplace from various cities in Slovakia.

Research objectives:

- Identify and compare the knowledge of holism and holistic nursing care within a holistic approach to the unconscious patient in nurses in the AIM workplaces from various cities in Slovakia.

- Identify and compare documentation of satisfying the needs of an unconscious patient in the AIM workplaces from various cities in Slovakia.

- Monitor the holistic approach to nursing care of the unconscious patient at the AIM workplace from various cities in Slovakia.

\section{Material and methods}

In the research area, we used a causal comparative research, ex - post facto. The research was realised in the months from March to October 2010 in nurses working in the AIM workplaces in Presov, Partizanske, Stara Lubovna, Vranov, Martin, Ruzomberok and Bardejov. All participants were informed in an adequate extent the research project and agreed to cooperate. To determine the individual components of the research we used the method of data collection by questionnaire and observation sheet. For statistical processing of our data, we used SPSS 15.0 software, Skewness test, nonparametric statistics, descriptive statistics, Kruskall-Waliss test for multiple independent selections and Mann-Whitney test for two independent selections.

Totally 158 nurses were participated in our research, we tried to compared them statistically based on the number of individual towns and sex. The final set of research ultimately consisted of 133 nurses.

Research hypotheses:

H1: We expect that knowledge of holism and holistic nursing care within a holistic approach to the patient who is unconscious will not significantly differ from respect to the place of occupation of a nurse.

$\mathrm{H} 2$ : We assume that the more objective quality of realization and recording of nurses holistic approach to unconscious patient in the AIM workplaces will significantly differ from respect to the place of occupation of a nurse. 


\section{Results}

The research results presented on figures 1-3.

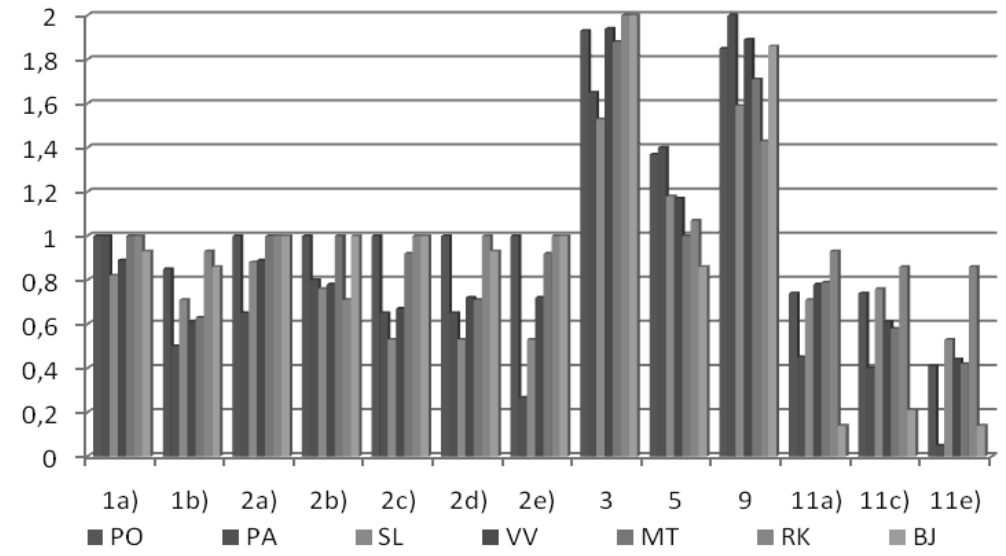

Figure 1. Knowledge of holism and holistic nursing care

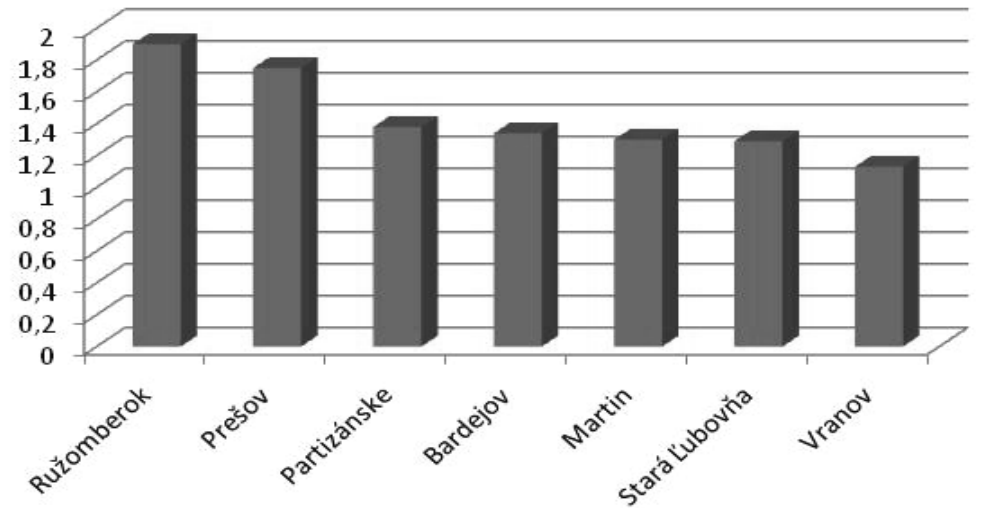

Figure 2. Comparison of average values of objectified quality realization and recording of the holistic approach to an unconscious patient in the AIM workplaces

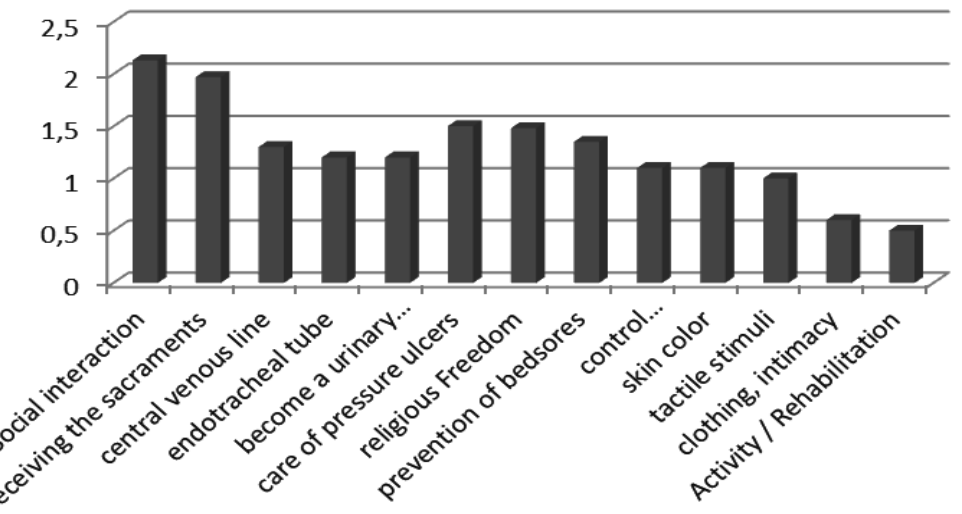

Figure 3. Comparison of average values of objectified quality realization and recording of the holistic approach to an unconscious patient in the particular categories.

- Only nurses from Presov considered necessary to provide holistic nursing care in all hospitalized patients.

- The most of nurses from Ruzomberok considerred necessary to record the satisfaction of psychological, spiritual and cultural needs of the patient to health care documentation.

- The most of nurses from Stara Lubovna wrote down the records of saturation, biological, social and spiritual needs of the patient in health care documentation.

- Objectified quality of realization and recording of a holistic approach of nurses in the AIM workplace statistically significantly differ from regarding the place of occupation of a nurse. 


\section{Discussion and conclusions}

Based on the research results we would like to argue and agree with Cumbie (Cumbie, 2001), that the application of a holistic approach to nursing care of the patient who is unconscious requires widening the professional knowledge of nurses, their practical and clinical skills, and all this meets the needs of the patient in a holistic sense.

Recommendations for practice - we suggest the following activities:

1. Monitor the latest knowledge in the field of holism and provide the holistic nursing care as well.

2. Provide nursing care according to the standards developed and revised standards in accordance with the latest knowledge.

3. Monitor legislative changes and effectively implement them in clinical nursing practice.

4. Consistently and accurately document nursing care, as well as the patient's response to it.

5. Apply a holistic approach to the issue of patient health standards in health care, which is an important condition for improving the quality of provided health care.

Knowledge of basic needs form the theoretical basis for nursing process and its application in practice. Assessment of the patient needs who is unconscious is the basis for assessing the patient including the problems and priorities in planning nursing interventions. To provide holistic nursing care if the patient is unconscious, selecting the systematic and comprehensive approach is an important method. This is the secure method of using the nursing process and complexity of the chosen treatment model.

\section{References:}

1. Cumbie SA. (2001), The integration of mind - body - soul and the practice of humanistic nursing. Holistic Nursing Practice. č. 15, p. 56-62.

2. Horňáková A. (2008), English in Emergency. Presov: PU Prešov, FZ.

3. Kapounová G. (2007), Ošetřovatelství v intenzívní péči. Grada Publishing. Praha.

4. Morton PG., Fontaine D., Gallo BM. (2005). Holistic Nursing: A Handbook for Practice.

5. Paseková M. (1996), Ludské potreby ako ošetrovatelský problém. Revue ošetrovatel'stva a laboratórnych metodík. roč. II, č. 2., p.51.

6. Pavlíková S. (2006), Modely ošetřovatelství v kostce. Praha: Grada Publishing

7. Rybárová D., Argayová I. (2011), Rozhodnutia na konci života v intenzívnej starostlivosti. Zborník X. Žiarsky sesterský deň 18. 3.2011. p. 147-154.

8. Trachtová E. et al. (2001), Potřeby nemocného v ošetrovatelském procesu. Brno: IDV PZ. 